\title{
Article
}

\section{New insights into maternity care design and delivery. Editorial commentary}

Downe, Soo

Available at https://clok.uclan.ac.uk/24367/

Downe, Soo orcid iconORCID: 0000-0003-2848-2550 (2018) New insights into maternity care design and delivery. Editorial commentary. Minerva

Ginecologica . ISSN 0026-4784

It is advisable to refer to the publisher's version if you intend to cite from the work. 10.23736/S0026-4784.18.04299-5

For more information about UCLan's research in this area go to

http://www.uclan.ac.uk/researchgroups/ and search for < name of research Group>.

For information about Research generally at UCLan please go to http://www.uclan.ac.uk/research/

All outputs in CLoK are protected by Intellectual Property Rights law, including Copyright law. Copyright, IPR and Moral Rights for the works on this site are retained by the individual authors and/or other copyright owners. Terms and conditions for use of this material are defined in the policies page.

\section{CLoK}

Central Lancashire online Knowledge www.clok.uclan.ac.uk

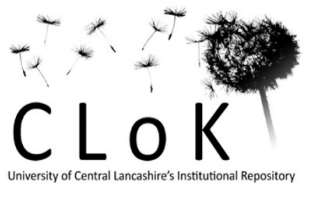




\title{
New insights into maternity care design and delivery: editorial commentary
}

\author{
Soo DOWNE * \\ Research in Childbirth and Health Unit (ReaCH), School of Community Health and Midwifery, University of \\ Central Lancashire, Preston, UK \\ *Corresponding author: Soo Downe, Research in Childbirth and Health Unit (ReaCH), School of Community Health and Midwifery, \\ University of Central Lancashire, Preston, UK. E-mail: sdowne@uclan.ac.uk
}

$\mathrm{T}$ his series of articles sets the design and delivery of Italian maternity care within the global arena, in terms of guidelines for practice; the design of labor wards and birth spaces; medical and midwifery education; the impact of the media; and the views and experiences of those who use the maternity services.

There are significant changes occurring globally in relation to the official framing of health care in general, ${ }^{1}$ and maternity care in particular. ${ }^{2}$ This is captured broadly in the United Nations (UN) millennium development goals, that are now focused on enhanced wellbeing, as well as on the need to reduce mortality and morbidity. ${ }^{3}$ Specifically, in terms of women and adolescent girls, the UN is proposing a move from immediate clinical "survival" alone, to a whole-life notion of "Survive, Thrive, Transform." 4 This is picked up in global dialogue about respectful care, 5 and a recognition by the World Health Organization (WHO) that optimal maternity care is a combination of both safety and positive well-being. ${ }^{6}$ It also reflects an increasing awareness that what happens during pregnancy, labor and birth probably has effects into the medium and longer term (and even potentially transgenerationally) for the mother and the baby. ${ }^{7,8}$ This includes increasing concern about the iatrogenic risks of interventions that are undertaken "too much too soon" as well as those undertaken "too little too late." "Cesarean section and widespread induction of labor are both included in the list of procedures undertaken "too much too soon" in some contexts and for some women and babies, as well as in the list of those undertaken "too little too late" for other populations and individuals. ${ }^{9}$ The implications of this for fathers, parents, families and societies is also generating debate, as is recognized, for instance, in the endorsement by the International Federation of Gynecology and Obstetrics (FIGO) and the International Confederation of Midwives (ICM) among others of the new evidence based International Childbirth Initiative 12 steps for MotherBaby-Family friendly maternity care. 10

There are a number of parallel movements happening in maternity care in Italy, including the creation of birth centers, and the evidence from some sites of positive collaboration between women, midwives, obstetricians, and others working in maternity care. As Skoko et $a l$. have noted in their article published in the present issue of Minerva Ginecologica, ${ }^{11}$ there is evidence of good practice around Italy from the Italian Babies Born Better survey of the views of women who have children under the age of 5. In recognition of the global move towards the need for health services to promote thriving, the authors note that there are areas 
of Italy where respondents to the survey only provided positive comments. It is possible that some of these responses were promoted by positive childbirth environments (for women and for staff).

Setola et al. ${ }^{12}$ pursue this possibility in their case studies of the architectural design of, and philosophy behind, two Italian birth centers. As for the other papers in this issue, the conscious creation of the conditions in which positive human relationships can thrive seems to be a key component of the success of these birth centers. Morano et al. ${ }^{13}$ present another facet of this so called "mechanism of effect" in their examination of the integration (or not) of a range of humanities subjects into the Italian medical and midwifery undergraduate curriculum. Intriguingly, and against expectation, they find that the differences are not so much between disciplines (though there is some evidence of this), but within each discipline. This means that professionals with the same qualification may have very variable exposure to the knowledge and insights from the humanities. This is particularly concerning in terms of the very low percentage of medical and midwifery schools that integrate ethics into their formal curriculum, given the highly complex ethical dilemmas that can emerge during the maternity episode.

Italy has one of the highest caesarean section rates in Europe, second only to Cyprus. ${ }^{14}$ Some of the issues underneath this statistic are also explored by Skoko et al. ${ }^{11}$ In addition, they are picked up by Hadjigeorgiou et al. ${ }^{15}$ who examine the way the media report on matters relating to maternity care in both Italy and Cyprus. They contrast these findings with the approach of the media in Iceland, which has one of the lowest caesarean section rates in the world, ${ }^{14}$ as well as one of the lowest perinatal mortality rates. ${ }^{16}$

In a further analysis of what could underpin different practices and outcomes across Europe, Iannuzzi et al. ${ }^{17}$ examine national ANC guidelines in 11 European countries, in relation to the recent WHO ANC guidelines. Again, the story is of variation, even though most national guideline stakeholder groups use a similar evidence base. Part of the variation is explained by the different kinds of philosophies that guide maternity care in each country, with an increasing emphasis in most (but not all) national guidelines on the balance between clinical practice and maternal views, experiences, and values.

To sum up, there is an increasing move towards recognizing the importance of emotional and psychosocial elements of maternity care. This Series shows that when women are asked, many do report some very positive experiences from their Italian maternity care. However, this is variable, with particular geographical areas of the country where the story is less positive overall. This variation in the quality and design of maternity care is reflected in maternity unit architecture, in media coverage of maternity care between countries, and in the inter-country content and uptake of national guidelines. Comparisons both between the local and regional maternity care services of a specific country (such as Italy) can identify the locations and reasons for best practice and serve as examples of such good care for less well performing local units. At the international level, the comparisons undertaken in this Series also indicate that improvement in outcomes and in women's experiences of both safe and personalized care require a willingness to find out how the best performing countries and services organize and deliver maternity care. Enabling positive, empowering relationships between and among service using women and their partners, and maternity service staff and managers, seems to be critical. In the international arena, there is a move towards 'Asking Different Questions'18 for maternity care. These proposals underpin a new research agenda to restore the balance between the 'too little too late' and the 'too much too soon' extremes that drive different philosophies of maternity care. The intention is to address both excessively high levels of iatrogenic intervention in some environments, and dangerously low levels of care delivery in others, while maximizing optimal wellbeing in both the short and longer term. As this Series indicates, learning from the best, within and between European countries with different kinds of service design, philosophy and outcomes, has the potential to benefit everyone, now, and into future generations. 


\section{References}

1. World Health Organization. Framework on integrated, people-centred health services; 2016 [Internet]. Available from: http://apps.who.int/gb/ebwha/pdf_files/WHA69/A69_39-en. pdf?ua $=1$ [cited 2018, Oct 9].

2. Shaw D, Guise JM, Shah N, Gemzell-Danielsson K, Joseph KS, Levy B, et al. Drivers of maternity care in highincome countries: can health systems support woman-centred care? Lancet 2016;388:2282-95.

3. United Nations. Sustainable Development knowledge platform. Transforming our world: the 2030 Agenda for Sustainable Development [Internet]. Available from: https://sustainabledevelopment.un.org/post2015/transformingourworld [cited 2018, Oct 9].

4. UN Sustainable Development Goals - Every Woman Every Child. The Global Strategy for Women's, Children's and Adolescent's Health (2016-2030): Survive Thrive Transform; 2015 [Internet]. Available from: www.who.int/life-course/ partners/global-strategy/ewec-globalstrategyreport-200915. pdf?ua $=1$ [cited 2018, Oct 9].

5. Bohren MA, Hunter EC, Munthe-Kaas HM, Souza JP, Vogel JP, Gülmezoglu AM. Facilitators and barriers to facilitybased delivery in low- and middle-income countries: a qualitative evidence synthesis. Reprod Health 2014;11:71.

6. World Health Organization. Recommendations on intrapartum care for a positive childbirth experience; 2018 [Internet]. Available from: http://apps.who.int/iris/bitstream/hand le/10665/260178/9789241550215-eng.pdf?sequence $=1$ [cited 2018, Oct 9].

7. Peters LL, Thornton C, de Jonge A, Khashan A, Tracy M, Downe $\mathrm{S}$, et al. The effect of medical and operative birth interventions on child health outcomes in the first 28 days and up to 5 years of age: A linked data population-based cohort study. Birth 2018. [Epub ahead of print]

8. Dahlen HG, Kennedy HP, Anderson CM, Bell AF, Clark A, Foureur M, et al. The EPIIC hypothesis: intrapartum effects on the neonatal epigenome and consequent health outcomes. Med Hypotheses 2013;80:656-62.

9. Miller S, Abalos E, Chamillard M, Ciapponi A, Colaci D,
Comandé $\mathrm{D}$, et al. Beyond too little, too late and too much, too soon: a pathway towards evidence-based, respectful maternity care worldwide. Lancet 2016;388:2176-92.

10. The International Childbirth Initiative (ICI). 12 Steps to Safe and Respectful MotherBaby-Family Maternity Care [Internet]. Available from: www.internationalchildbirth.com/ about.html [cited 2018, Oct 9].

11. Skoko E, Ravaldi C, Vannacci A, Nespoli A, Akooji N, Balaam MC, et al. Findings from the Italian Babies Born Better (B3) survey. Minerva Ginecol 2018. [Epub ahead of print]

12. Setola N, Iannuzzi L, Naldi CE, Escuriet Peiro R, Morano S, Santini M. Optimal Settings for Childbirth. Minerva Ginecol 2018. [Epub ahead of print]

13. Morano S, Lotti A, Canepa MM, Sterrantino G, Beleva $\mathrm{D}$, Iannuzzi L, et al. Humanities in the undergraduate medical and midwifery curriculum: a descriptive Italian comparative study. Minerva Ginecol 2018. [Epub ahead of print]

14. European Health Information Gateway. Caesarean sections per 1000 live births; 2018 [Internet]. Available from: https://gateway.euro.who.int/en/indicators/ hfa_596-7060-caesarean-sections-per-1000-live-births/ visualizations/\#id=19691 [cited 2018, Oct 9].

15. Hadjigeorgiou E, Spyridou A, Christoforou A, Iannuzzi L, Giovinale S, Canepa MM, et al. Variation in caesarean section rates in Cyprus, Italy and Iceland: an analysis of the role of the media. Minerva Ginecol 2018. [Epub ahead of print]

16. European Health Information Gateway. Perinatal deaths per 1000 births; 2018 [Internet]. Available from: https:// gateway.euro.who.int/en/hfa-explorer/\#VMNsbovlz4 [cited 2018, Oct 9].

17. Iannuzzi L, Branchini L, Clausen JA, Ruiz-Berdún D, Gillen P, Healy M, et al. Optimal outcomes and women's positive pregnancy experience: a comparison between the World Health Organization guideline and recommendations in European national antenatal care guidelines. Minerva Ginecol 2018. [Epub ahead of print]

18. Kennedy HP, Yoshida S, Costello A, Declercq E, Dias MA, Duff E, et al. Asking different questions: research priorities to improve the quality of care for every woman, every child. Lancet Glob Health 2016;4:e777-9.

Conflicts of interest.- The author certifies that there is no conflict of interest with any financial organization regarding the material discussed in the manuscript.

Acknowledgements. - The author wishes to thank all the authors of this series, who contributed to the detailed ideas, data, and analysis that underpin this commentary, and to the Italian women who completed the Babies Born Better survey.

Article first published online: September 13, 2018. - Manuscript accepted: August 31, 2018. - Manuscript received: August 23, 2018.

(Cite this article as: Downe S. New insights into maternity care design and delivery: editorial commentary. Minerva Ginecol 2018;70:000-000. DOI: 10.23736/S0026-4784.18.04299-5) 